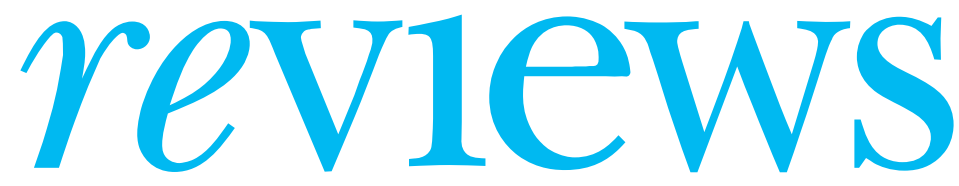

BOOKS • CD ROMS • ART •WEBSITES $\bullet$ MEDIA $\bullet$ PERSONAL VIEWS $\bullet$ SOUNDINGS

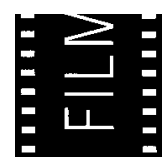

\section{Ways of seeing}

\section{A documentary about going blind offers a powerful study in adaptation}

Black Sun, a film directed by Gary Tarn Cinema 1, ICA, The Mall, London SW1Y 5AH, until 25 May; Silverdocs Documentary Festival, outside Washington, DC, 13-18 June; Nantucket Film Festival, Massachusetts, 14-18 June; UK-wide theatrical distribution and screenings on $\mathrm{BBC}$ and $\mathrm{HBO}$ television to be confirmed

Rating: $\star \star \star \star$

$\mathrm{H}$ ugues de Montalembert was attacked and blinded in 1978, aged 36. The French artist and dedicated traveller describes his new life without sight-in film. Black Sun is a vibrant and moving impressionistic documentary that follows the next 20 years of his life, in an amazing journey around the world. And it's a personal and open portrayal of loss and grief, and an insight into what sight means to a blind person. The ultimate impression, though, is of an artist determined to continue his life as before.

De Montalembert narrates Black Sun, but his story includes visual narrative too-scenes inspired by those constructed in his brain as it tries to interpret the impaired input. He reasons that the existence of these manmade "visions" proves that sight is created internally, and is not a perception.

The lens pans soft focus across aerial views from high above New York: a million lights twinkle in the hazy purple dusk. "How many blind people have you met? Where are they?" he calmly asks. The camera zooms in on a crowded avenue, and then the edges of the streets and buildings become outlined in white, as if they're in a giant computer graphics program. White annotations line up neatly with the wire frames.

He relives the attack. Two drug deprived addicts force him at knifepoint into the New York flat that he's borrowed from a friend. Because he has nothing of valueand because he fights back-the intruders become angry. One throws paint stripper at him, and the noxious liquid burns his eyes. His screams scare off the attackers.
Frantically he bathes his eyes in the shower, but already he can feel his sight weakening. We see a kaleidoscope of blur and tunnel vision. At hospital he asks the doctor if it is serious, and the doctor says yes, very. And the next day, de Montalembert is blind. He's not in darkness, though-rather golden light "like falling into a pot of dark honey." Over the next few days his brain creates vivid, erotic, and disturbing images.

People start to treat de Montalembert differently-now nurses, doctors, and visitors bare their souls to him. He fears other people's reaction to his blindness. "When will you be able to see again?" a taxi driver asks him. De Montalembert learns to play the piano with one hand, the other hand reading the Braille score. He equates losing his sight with losing his masculinity, to castration. He grieves his loss as an artist and as a human being.

Initially he wants his blindness kept secret from his friends, family, and girlfriend. He thinks he wouldn't be able to console them. But they find out, and he has to ask his mother not to visit because he needs more time. His lover leaves him, as do other friends. "People don't like tragedy," he says. He tortures himself that without eye contact there cannot be love. And he despairs: "You never think it'll happen to you." But he's not prepared to accept a sedentary life.

He also fears having to give up his independence, to need help. "If I want something I know it will be difficult." And he associates blindness with a body defeated through age. Despite doctors' protests that he is not ready, encroaching depression spurs him to enrol in a rehabilitation centre. Upbeat footage shows white sticks, sight charts, Braille lessons, and obstacle courses in hospital corridors. He recalls in colour as he describes in delight the rush of excitement at sneaking out of the centre and walking seven blocks down Madison Avenue late one night.

Buildings change into clouds that change into cratered grassy wasteland in a flowing montage. At times the photography evokes nostalgia for summer holidays shot on super eight and at others is garish and synthetic. Computer enhancement transforms shots into technical drawings and thermal images, intense bursts of contrasting colours.
One and a half years later, De Montalembert tells no one and leaves New York for Indonesia. He depicts Bali in dazzling multicoloured thermograms, noisy red and green faces. Here he finds catharsis in writing. Sometimes, unwittingly, he keeps writing after his pen runs out. One time he continued for 12 pages, until his cook noticed.

A man in a bar tells him he looks like a painter. "Yes. How did you know?" de Montalembert asks. "The way you look at things." Travelling gives him new confidence and helps him to reaffirm his identity as an artist. He shares adventures from his travels with new optimism. Thieves steal all his possessions when he arrives in New Delhi, but they return his bags unopened when they realise that he is blind. In another anecdote, de Montalembert has to be convinced that he's never really seen one of his friends, because they met after the attack. However, de Montalembert claims to know exactly how he looks.

Black Sun is a sensitive account of personal loss set to stunning visuals-a study in frustration and adaptation that occasionally exposes genuine bitterness. Although de Montalembert would like to see again he says he's completely happy being blind. Black Sun is uplifting because rather than let his blindness confine him, de Montalembert uses it to try to understand what it means to be able to see.

Richard Hurley technical editor, BMJ rhurley@bmj.com

Items reviewed are rated on a 4 star scale (4=excellent) 


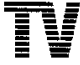

\section{Hollywood fights bird flu}

\section{An entertaining worst case scenario}

Fatal Contact: Bird Flu in America, a film on $\mathrm{ABC}$ television, aired in the United States on 9 May 2006

$\mathrm{S}$ what's bird flu going to be like, assuming that it comes? In this television movie we get to see all the scary things the writers have learned about a possible avian influenza pandemic crammed into two hours: a highly virulent, rapidly transmissible virus, inept attempts at containment, overwhelmed medical facilities, mass graves, food and water shortages, and looting and rioting.

The programme begins with a solemn disclaimer telling us that the $\mathrm{H} 5 \mathrm{~N} 1$ virus has not (yet) been transmitted from person to person. Cut to geese flying over the ocean and chickens being slaughtered by the million in China. The virus has mutated and is spreading among the Chinese in a market town soon to be visited by an American businessman. He catches it from a coughing factory worker and then begins shedding virus as he travels home. In dramatically effective microscopic close-ups now common on television shows such as CSI: Crime Scene Investigation, a graphic portrayal of forensic police work, viral particles are shown being passed to unsuspecting people via serviettes, martini olives, hot face towels, and handshakes.

The hero of the story is, of course, a beautiful blonde, an Epidemic Intelligence Service (EIS) officer played by Joely Richardson, who is rather wooden and has traces of her English accent remaining. She is called away from a tryst to fly to China to confirm that the virus has mutated. She then breaks the news to the US health secretary and they convene a meeting of state governors to inform them that bird flu is on the way.

The rest of the movie follows the pandemic through three major story threads: the death of the index case and the grief, quarantine, emotional paralysis, recovery, and subsequent community leadership of his widow; the mistakes made by the governor of Virginia and his redemption after losing his son and realising that quarantine is not the answer; and the everyday heroism of a New York City emergency room nurse and her National Guard husband.
Gripping stuff, mostly very well done. Particularly effective visual scenes include a vast temporary hospital set up in a New York subway station and a huge burial pit into which trucks dump hundreds of wrapped bodies. And likely problems-such as a shortage of medications, the time lag until a vaccine is developed, and the problems of rationing both-are realistically portrayed.

There are some scientific inaccuracies. It makes no sense to quarantine people beyond influenza's four day incubation period, so the Virginia governor's prolonged quarantine of portions of Richmond with fences and barbed wire seems unlikely. Migrating wild birds are made out to be the big villains, although we've now learned that they don't, in fact, seem to be transmitting the virus. But these are rather minor slips.

What the movie does very well is to entertain and get people thinking. I watched it with two teenagers who paid rapt attention and kept asking whether this could really happen and what we would do about it if it did. Good questions.

\section{Douglas Kamerow US editor, BMJ}

dkamerow@bmj.com

The US Centers for Disease Control has prepared a viewer's guide to provide answers: http://pandemicflu.gov/news/birdfluinamerica. html\#guide.

\section{The Medical Detective: John Snow and the Mystery of Cholera \\ Sandra Hempel}

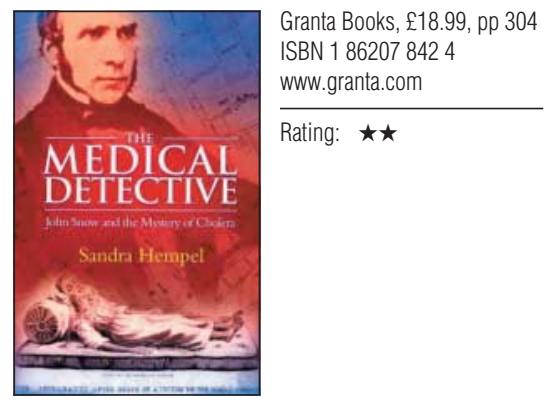

$\tau$ ohn Snow is perhaps the only doctor ever to be considered the founder of two medical disciplines: epidemiology and anaesthesiology. An early believer in the theory of contagion, he grasped the opportunity of a peculiarity in the water supply in London to gather quantitative evidence supporting his theory that cholera was transmitted by polluted water.

In 1853-4, when a cholera pandemic hit London, one of the two major water supply firms, the Lambeth Company, had moved its Thames intakes upriver, above the tidal (and therefore sewage) reach. Snow showed that most of the cholera deaths occurred among clients of the other major water provider, the
Southwark and Vauxhall Company, which still pumped its water in a polluted area of the Thames in the heart of London. We know a great deal about Snow's large scientific heritage because he was a prolific writer. But very little written testimony exists about his personal life and psychology beyond an expanded obituary.

Given the limited biographical material available, it seems that everything that might be written about Snow has already been said by other authors, or collected by Frerichs on a website devoted to Snow (www.ph.ucla. edu/epi/snow.html). Indeed, Snow's fans will not learn anything new about him in The Medical Detective. Still, Sandra Hempel has succeeded in drawing a three-dimensional portrait of Snow by abundantly describing the place, time, and society in which he lived.

The Medical Detective reads like a well informed novel featuring Chadwick and Dickens, Queen Victoria and Florence Nightingale, and digressions on the history of Victorian medicine, of ether and chloroform, and of cholera. A mythical image of Snow as a brilliant doctor with a penetrating intuition about the cause of cholera and who ingeniously found a way to test it emerges. However, in contributing to Snow's mythology, Hempel fails to address some basic questions any detective would ask. Why Snow? Why London? After all, many bright physicians in Europe and elsewhere were tracking the causes of cholera at the same time. Many shared his contagionist views. But Snow lived in an appropriate socio-political and scientific environment. He had the opportunity to team up with William Farr, medical registrar for England and Wales, whose offices collected death certificates and reported their aggregated numbers weekly.

A key figure of Victorian medicine, Farr played a crucial role in Snow's success, which is not appreciated as much as it should be by Hempel. In December 1853, the registrargeneral had first noticed that the districts partially supplied with the improved water from the Lambeth Company suffered much less than the other districts from cholera, although, previously, these same districts suffered about as much as those supplied entirely by the Southwark and Vauxhall Company. Farr provided Snow with the names and addresses of the dead and made Snow's demonstration possible. Farr did not share Snow's views on the role of polluted water, but he was instrumental in the success of Snow's endeavour.

Snow is already the hero of an excellent children's book (The Blue Death: The True Story of a Terrifying Epidemic. London: Hodder Children's Books, 2001). Hempel has now staged him as a brilliant detective and paved the road for a popular movie, which will finally let Snow enter the pantheon of great doctors.

Alfredo Morabia professor of epidemiology, City University of New York, United States am52@columbia.edu 


\section{Which patients with which needs are leading the patient-led NHS?}

I

t was the summer of 1992 when we first met. She was a retired nurse, aged 76 ,

recovering from a heart attack. I was new to the practice, and we talked at some length. She told me about her work in the hospital, her children and grandchildren. And we talked about my experiences on the same wards and my growing family. She was checking out the new doctor, while I was putting into practice the "bio-psychosocial" approach drummed into us as we prepared for our college membership exams.

A few months later I was called to see her at home. She was short of breath and showing the first signs of heart failure. We talked about medication, investigations, or outpatient referral. She wanted as little "interference" as possible-preferably never to go near hospital again. We worked our way through various treatments and her symptoms improved a little. But gone were the daily walks to the baker or the newsagent-a few steps down the path became all

practice where everyone knew her was infinitely more important than "instant access for routine care at anytime" that seems to drive the white paper. But then she was not middle-aged, middle class, and living in middle England. She rated the quality of her personal care very highlyfrom the reception team to the visiting nurses and general practitioners. I don't think her view would have changed even if she had known that her care fell short in many areas of the Quality and Outcomes Framework (QoF)-indicators for which GPs receive payments as part of their contract.

A few weeks ago she suffered another heart attack followed by a stroke, and never returned home. She died peacefully this week in a local "continuing care" bed, at the age of

90. We had been on life's journey together over 14 years - the epitome of what I had hoped and believed general practice would be about when I began my training at medical school. Last night I opened her computer notes to record a could manage. Nevertheless, she remained invariably cheerful, playing host to several groups of medical students, helping them with their "chronic disease" projects. I called in every now and then to monitor her progress on an ad hoc basis, yet she always managed to have a plate of sandwiches waiting.

Over time her symptoms gradually worsened. Later she developed diabetes, predictably difficult to control. We controlled her blood pressure with tablets, which worsened her renal function. A statin lowered her cholesterol, but her liver function went haywire. Her blood sugar rose inexorably, despite triple therapy, so we switched to insulin. She lived with her beloved grandson who took over administration of her injections, but her $\mathrm{H}_{\mathrm{b}} \mathrm{A}_{1 \mathrm{c}}$ remained stubbornly high. Beta blockers made her breathing worse and her warfarin had to be stopped after a gastric bleed. I continued to call in every month or two-there always seemed to be a new symptom or drug side effect to deal with. We tinkered with medication; introduced a nebuliser; and always had a good chat together, catching up on each other's families, exchanging photos. She ended up in hospital a couple of times but returned home after each admission full of determination to remain independent.

She is not the kind of patient who had the opportunity to fill in the "Your health, Your care, Your say" survey (www.nhs.uk/ yoursay) to inform the recent white paper on community care. But if she had been asked, I feel sure continuity of care from a section. These should be no more than 850 words and should be sent electronically via our website. For information on how to submit a personal view online, see http://bmj.com/cgi/content/full/325/ 7360/DC1/1

\section{SOUNDINGS}

\section{Souls in cages}

"Some are like souls in cages. Like, you can see they're there, but they look like they don't want to be." He tries to elaborate, can't take it much further, but-for a 17 year old on work experience in a nursing home and wanting to be a doctor-perhaps he's done quite well already.

Where do they come from, these souls in cages? Not sure, but I see too many of them: too often and too easily we fail the souls and build the cages. In the rush and glamour of acute care, in the busy system that is designed to cure and doesn't like to lose, there are priorities that may take insufficient account of the worse-than-death outcome-the helpless, stabilised, damaged survival-that so many of us dread. And too often families are summoned for the grimly absurdist routine: "We've saved your father's life . . But now he's blocking a bed."

The sorrows can endure for months or years. The death averted is a bereavement suspended, the caged soul lingers, and people remain upset. Is it about regrets, or a strange injustice, or a wider and far more worrying dysfunction? Who knows, but it seems to happen quite a lot.

Yesterday my mother was well. This morning her neighbour rang me to say she was not: "She kent me, but she couldna talk, and she couldna get up." I speak some Scots and know some neurology. It's very bad. Three hours later, in the emergency department of a decent district general hospital, I see her. Everyone has been kind and efficient, but she is now, in her grandson's words, a soul in a cage.

She was 90 in October and greatly enjoyed her birthday bash. Yesterday she logged yet another great grandchild into her fearsomely well organised birthday book, and had ordered but not yet collected her first walking stick. She had ticked all her boxes-two careers, bringing up her children, burying her husband-and since then has greatly enjoyed her bowling, her voluntary work, and a lively extended family. She cannot move her right side and cannot speak.

She is dying but she is lucky: no nasogastric tube or PEG (percutaneous endoscopic gastrostomy) feeding for her A few months ago she tidied up her life, perhaps anticipating eternity, and made her wishes clear. I pass them on and a wonderful district general hospital team respects them, cares lovingly for her, and will not cage her soul.

Colin Douglas doctor and novelist, Edinburgh 